\title{
Geographical variation in carbon stable isotope signatures of marine predators: a tool to investigate their foraging areas in the Southern Ocean
}

\author{
Yves Cherel ${ }^{1, *}$, Keith A. Hobson ${ }^{2}$ \\ ${ }^{1}$ Centre d'Etudes Biologiques de Chizé, UPR 1934 du Centre National de la Recherche Scientifique, BP 14, \\ 79360 Villiers-en-Bois, France \\ ${ }^{2}$ Environment Canada, 11 Innovation Boulevard, Saskatoon, Saskatchewan S7N 3H5, Canada
}

\begin{abstract}
Stable carbon isotope signatures $\left(\delta^{13} \mathrm{C}\right)$ are increasingly being used to determine the foraging habitats of consumers in the Southern Ocean. An underlying assumption is that a latitudinal gradient in $\delta^{13} \mathrm{C}$ values at the base of the food chain should also be reflected in organisms at higher trophic levels. Our main objective was to test that assumption by using penguin chicks ( 7 taxa) as predator models, because the feeding habits of provisioning adult penguins are well known during the chick-rearing period. As expected, a strong negative correlation was found between latitude and $\delta^{13} \mathrm{C}$ values of whole blood of penguin chicks. $\delta^{13} \mathrm{C}$ values ranged from $-24.8 \pm 0.5 \%$ in Adélie penguins living in Antarctica $\left(67^{\circ} \mathrm{S}\right)$, to $-19.5 \pm 0.3 \%$ in northern rockhopper penguins living in the subtropics $\left(38^{\circ} \mathrm{S}\right)$. Unlike $\delta^{13} \mathrm{C}$ values, stable nitrogen isotope signatures $\left(\delta^{15} \mathrm{~N}\right)$ were not related to latitude but instead were strongly affected by penguins' diet, with fish-eaters having higher $\delta^{15} \mathrm{~N}$ values than crustacean eaters. $\delta^{13} \mathrm{C}$ values also reflect more local spatial foraging segregation of penguins at a subantarctic archipelago (Kerguelen Islands), where they varied from $-22.3 \pm 0.2 \%$ o for king penguins feeding in oceanic waters to $-15.9 \pm 0.3 \%$ for gentoo penguins foraging in an enclosed bay. Blood $\delta^{13} \mathrm{C}$ values moreover allowed differentiation of 2 sub-populations of gentoo penguins foraging in 2 different environments at Kerguelen. The method has 2 limitations related to the lack of longitudinal variations and to overlapping $\delta^{13} \mathrm{C}$ values due to different isotopic gradients (latitudinal and inshore/offshore) in the marine environment. The study nevertheless shows that the $\delta^{13} \mathrm{C}$ values of marine predators are efficient indicators of the foraging habitats at various spatial scales, both in terms of latitude in oceanic waters, and in terms of inshore/offshore gradients in waters surrounding subantarctic islands.
\end{abstract}

KEY WORDS: Antarctica $\cdot$ Latitude $\cdot$ Marine foodweb $\cdot$ Carbon-13 $\cdot$ Nitrogen-15 $\cdot$ Penguin $\cdot$ Seabird Resale or republication not permitted without written consent of the publisher

\section{INTRODUCTION}

Establishing patterns of movements of free-ranging animals is crucial for a better understanding of their feeding ecology and life history traits, and is a prerequisite for their conservation. Tracking animal movements can be done directly using remote-sensing techniques or indirectly using biochemical markers like naturally occurring stable isotopes. The latter method has been increasingly utilized in the last decade on a variety of animals (Hobson 1999, Rubenstein \& Hobson 2004), including seabirds and marine mammals (Best \& Schell 1996, Cherel et al. 2000). The 2 most commonly used stable isotope ratios in ecology are those of nitrogen $\left({ }^{15} \mathrm{~N} /{ }^{14} \mathrm{~N}\right.$, measured as $\left.\delta^{15} \mathrm{~N}\right)$ and carbon $\left({ }^{13} \mathrm{C} /{ }^{12} \mathrm{C}, \delta^{13} \mathrm{C}\right)$. Consumers are typically enriched in ${ }^{15} \mathrm{~N}$ relative to their food and consequently $\delta^{15} \mathrm{~N}$ measurements serve as indicators of a consumer's trophic position (McCutchan et al. 2003, Vanderklift \& Ponsard 2003). By contrast, $\delta^{13} \mathrm{C}$ values vary little along 


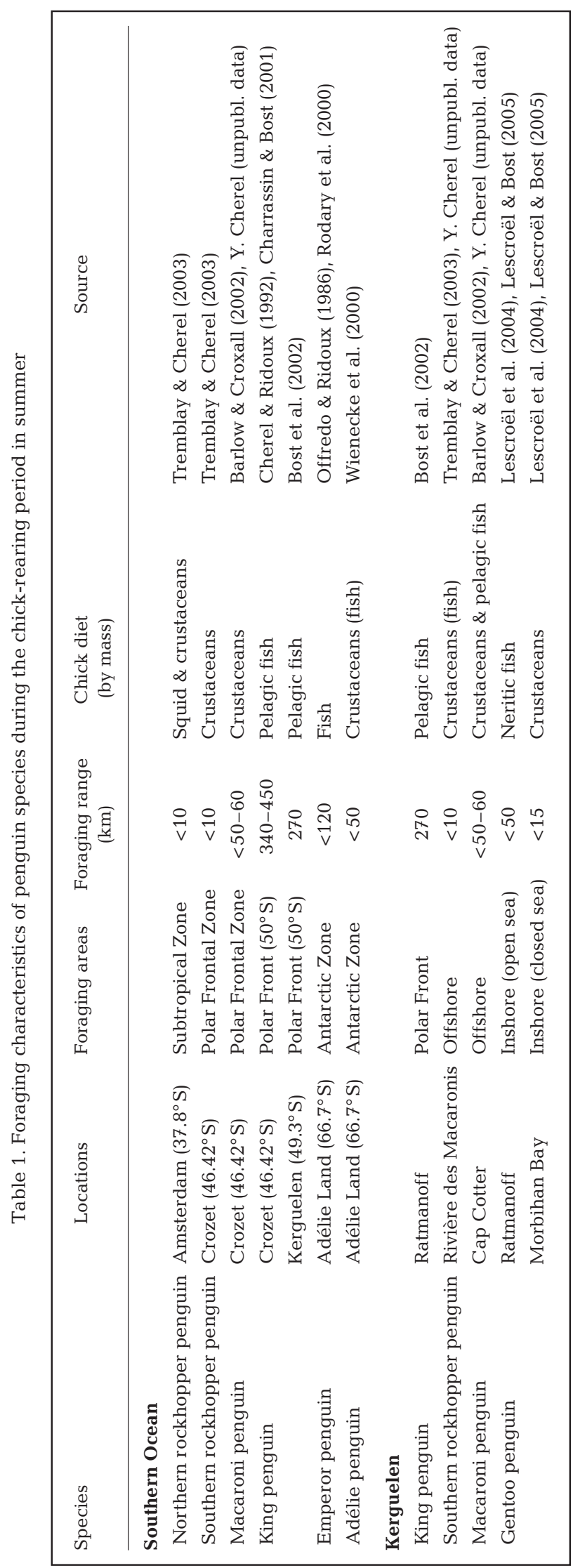

the food chain and are mainly used to determine primary sources in a trophic network (Kelly 2000, McCutchan et al. 2003). In the marine environment, the $\delta^{13} \mathrm{C}$ values can also indicate inshore versus offshore, or pelagic versus benthic contribution to food intake (Hobson et al. 1994).

In comparison to higher-latitude organisms, lowerlatitude plankton food bases (phytoplankton and particulate organic matter, POM) are enriched in ${ }^{13} \mathrm{C}$. In the southern hemisphere, the geographical $\delta^{13} \mathrm{C}$ gradient is well defined in POM from surface waters, ranging from high $\delta^{13} \mathrm{C}$ values in warm subtropical waters in the north to low values in cold Antarctic waters in the south (François et al. 1993, Trull \& Armand 2001), hence its use for the investigation of foraging areas of marine predators (Best \& Schell 1996, Cherel et al. 2000, 2006). An underlying crucial assumption of these studies is that stable isotope patterns at the base of the food chain should also be reflected in organisms at higher trophic levels. The assumption has not been tested, but one recent survey of the literature on seabirds supports it (Quillfeldt et al. 2005). This review, however, suffers 2 biases. First, it is based mainly upon the carbon signature of chicks of far-ranging species of procellariiforms. During the chick-rearing period, adult procellariiforms use a dual foraging strategy including trips in different feeding areas. Chicks are fed with prey collected in different water masses and they consequently have $\delta^{13} \mathrm{C}$ values different from those associated with foodwebs surrounding the breeding colonies (Cherel et al. 2005c). Second, Quillfeldt et al. (2005) used the isotopic values of different tissues (mainly blood and feathers). Due to different protein turnover rates and metabolic routines, those tissues are known to possess different isotopic signatures and diet-tissue isotopic discrimination factors (e.g. Hobson \& Clark 1992, Cherel et al. 2005b), thus including uncontrolled and potentially confounding parameters in the analysis.

The main objective of the present study was to test the relationships between the isotopic signature of predators versus latitude in the Southern Ocean (south of the Subtropical Front). We chose penguin chicks for several practical and ecological reasons. First, our penguin colonies are located at various sites encompassing a wide latitudinal range, from the subtropical Amsterdam Island to Adélie Land, Antarctica (Table 1). We also investigated the relationship at a smaller spatial scale, within the Kerguelen Archipelago, because an extensive peri-insular shelf surrounds it, and the mainland includes a large enclosed bay where penguins are known to have different feeding habits (Lescroël \& Bost 2005). The Kerguelen Archipelago thus offers a good opportunity to examine a complex inshoreoffshore gradient in the marine environment. Second, 
a lot of information is available on the feeding habits of penguins during the chick-rearing period (Table 1). Since they do not fly and adults are central-place foragers, unlike procellariids, their foraging range is limited and most of them stay within $50 \mathrm{~km}$ of the colonies at that time. A notable exception is the king penguin. Whatever the locality, king penguins forage in waters of the Polar Front (Pütz 2002), and it was therefore considered to be representative of that area in summer. Finally, we used whole blood as the target tissue, because it is the easiest tissue-with feathers - that can be non-destructively sampled in the field. Blood has also the advantage that its generally low lipid content does not necessitate lipid extraction (Cherel et al. 2005b), and its isotopic signature is only marginally affected by the nutritional status of the animals (Cherel et al. 2005a).

\section{MATERIALS AND METHODS}

Fieldwork was carried out during the austral summers 2001 to 2002 and 2002 to 2003 in the Terres Australes et Antarctiques Françaises, i.e. in Adélie Land, Antarctica, and at 3 sites in the Southern Indian Ocean, the Kerguelen, Crozet and Amsterdam Islands (Table 1). According to physical oceanography, coastal Adélie Land lies in the Antarctic Zone (south of the Polar Front), Kerguelen and Crozet Archipelagoes in the Polar Frontal Zone (between the Polar Front and the Subantarctic Front) and Amsterdam Island in the Subtropical Zone (north of the Subtropical Front, i.e. slightly outside the Southern Ocean) (Park et al. 1993). Amsterdam Island is devoid of peri-insular shelf and is thus directly surrounded by oceanic waters, Crozet is a medium-sized archipelago with a relatively small shelf, but Kerguelen is the second largest archipelago in the Southern Ocean after the Falkland Islands. Its coastline is jagged by numerous fjords and bays, the largest of these bays, Morbihan Bay (located in the eastern part of the archipelago), being a very productive sheltered area where numerous seabirds, including penguins, breed.

We investigated 7 penguin taxa: 3 crested penguins (the northern Eudyptes chrysocome moseleyi and southern E. chrysocome filholi rockhopper penguins, and the macaroni penguin E. chrysolophus), 2 pygoscelids (the gentoo Pygoscelis papua and Adélie $P$. adeliae penguins) and the 2 species of the genus Aptenodytes (the king A. patagonicus and emperor $A$. forsteri penguins). For each penguin species, 8 to 11 large chicks were randomly chosen at each breeding location. Blood was collected via venipuncture of one flipper vein with heparinized syringes. Seventypercent ethanol was then added to whole blood, be- cause, in many cases, freezing was not possible in the field and storage in ethanol does not alter the isotopic composition of tissues (Hobson et al. 1997). Samples were subsequently kept at $-20^{\circ} \mathrm{C}$ until isotopic analysis.

Relative abundance of stable isotopes of carbon and nitrogen in whole blood were determined by continuous-flow isotope-ratio mass spectrometry. Results are presented in the usual $\delta$ notation relative to PDB belemnite and atmospheric $\mathrm{N}_{2}$ (Air) for $\delta^{13} \mathrm{C}$ and $\delta^{15} \mathrm{~N}$, respectively. Replicate measurements of internal laboratory standards indicate measurement errors of \pm $0.1 \%$ and $\pm 0.3 \%$ or $\delta^{13} \mathrm{C}$ and $\delta^{15} \mathrm{~N}$, respectively. Values are means \pm SD. Data were statistically analyzed using SYSTAT 9 for WINDOWS.

\section{RESULTS}

Penguin chicks from various localities segregated by their overall isotopic signatures (MANOVA, Wilk's Lambda, $\left.F_{12,114}=188.92, \mathrm{p}<0.0001\right)$ and, in univariate analysis, both $\delta^{15} \mathrm{~N}$ (ANOVA, $\left.F_{6,58}=154.99, \mathrm{p}<0.0001\right)$ and $\delta^{13} \mathrm{C}$ values of whole blood $\left(F_{6,58}=346.95, \mathrm{p}<\right.$ 0.0001). As expected, a strong negative correlation was found between latitude and blood $\delta^{13} \mathrm{C}$ valuebut not $\delta^{15} \mathrm{~N}$ values - of penguin chicks (Spearman rank-test, $\mathrm{n}=7, \mathrm{r}_{\mathrm{s}}=0.982, \mathrm{p}<0.005$ ) (Fig. 1). Stable carbon isotope signatures varied from $-24.8 \pm 0.5 \%$ in Adélie penguins from Adélie Land, Antarctica, to $-19.5 \pm 0.3 \%$ in northern rockhopper penguins from the subtropical Amsterdam Island. Blood $\delta^{13} \mathrm{C}$ values differed among species with the exception of king penguins at Crozet and Kerguelen Islands, and of macaroni and southern rockhopper penguins at Crozet (post hoc Tukey HSD multiple comparison tests).

Stable nitrogen isotope values ranged from $6.8 \pm$ $0.3 \%$ o (southern rockhopper penguins from Crozet) to $12.4 \pm 0.7 \%$ o (emperor penguins from Adélie Land), and differed among species with the exception of the Adélie penguin and king penguins from Crozet and Kerguelen Islands (post hoc Tukey HSD multiple comparison tests) (Fig. 1).

Segregation was also found at the scale of Kerguelen Archipelago, where penguin chicks differed by their overall isotopic signatures (MANOVA, Wilk's Lambda, $\left.F_{8,84}=68.75, \mathrm{p}<0.0001\right)$, and in $\delta^{15} \mathrm{~N}$ (ANOVA, $F_{4,43}=$ 88.24, $\mathrm{p}<0.0001)$ and $\delta^{13} \mathrm{C}$ values $\left(F_{4,43}=143.76, \mathrm{p}<\right.$ 0.0001). Post hoc Tukey HSD multiple comparison tests indicated that all chicks differed significantly in $\delta^{15} \mathrm{~N}$ and $\delta^{13} \mathrm{C}$ values except the macaroni and southern rockhopper penguins. When $\delta^{13} \mathrm{C}$ values were deliberately placed in an increasing sequence, the sequence strongly reflects the known adults' foraging areas (Fig. 2). $\delta^{13} \mathrm{C}$ values varied from $-22.3 \pm 0.2 \%$ or king penguins feeding in oceanic waters of the Polar Front 


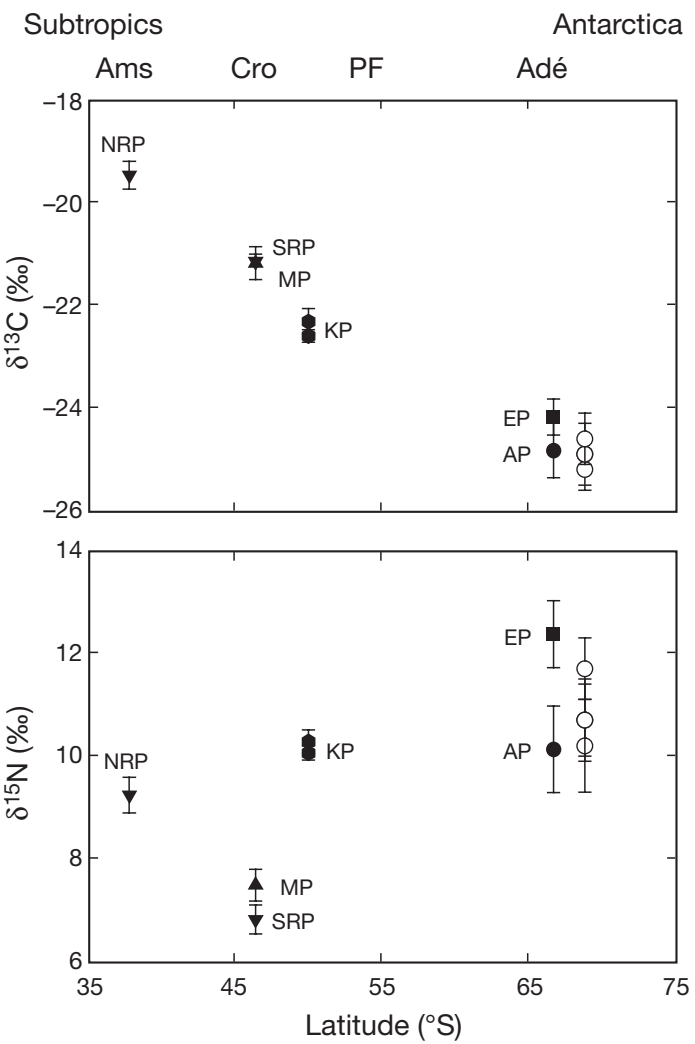

Fig. 1. Relationship between the carbon (upper panel) and nitrogen (lower panel) isotopic signatures of penguin chick blood (filled symbols) and latitude of sampling locations/foraging areas in the Southern Ocean. Open symbols refer to the blood signature of 4 species of Antarctic fulmarine petrels (Hodum \& Hobson 2000). NRP: northern rockhopper penguin, SRP: southern rockhopper penguin, MP: macaroni penguin, KP: king penguin, EP: emperor penguin, AP: Adélie penguin. Ams: Amsterdam, Cro: Crozet, PF: Polar Front, Adé: Adélie Land. Values are means $\pm \mathrm{SD}$

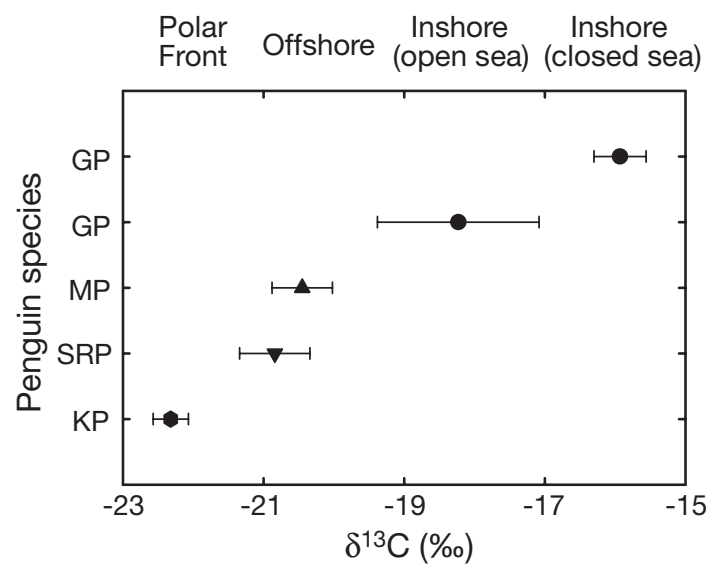

Fig. 2. Stable carbon isotope signature of penguin chick blood and adult foraging areas during the chick rearing period at Kerguelen Islands. GP: gentoo penguin, MP: macaroni penguin, SRP: southern rockhopper penguin, KP: king penguin. Values are means $\pm \mathrm{SD}$ to $-15.9 \pm 0.3 \%$ for gentoo penguins foraging in the enclosed Morbihan Bay, with intermediary values reached by the 2 species of offshore-forager crested penguins. Interestingly, the carbon signatures of gentoo penguin chicks whose parents fed in 2 contrasted marine environments were different, open-sea birds having lower $\delta^{13} \mathrm{C}$ values than closed-sea penguins (Fig. 2).

\section{DISCUSSION}

\section{Variation of penguin $\delta^{13} \mathrm{C}$ values in the Southern Ocean}

We verified the assumption that $\delta^{13} \mathrm{C}$ patterns at the base of the food chain should be also reflected in organisms at higher trophic levels in the Southern Ocean. A strong negative correlation was found between latitude and the $\delta^{13} \mathrm{C}$ signature of blood of top predators, with a maximum difference of $5.3 \%$ between the subtropical and Antarctic penguin species. The only other available data on blood $\delta^{13} \mathrm{C}$ values of seabirds from the Southern Ocean fit well with our results (Fig. 1). The $\delta^{13} \mathrm{C}$ signature of 4 Antarctic procellariiforms that are known to forage exclusively in Antarctic waters during breeding were indeed very negative (Hodum \& Hobson 2000). Literature surveys of intermediary organisms (including penguin prey) in the trophic web of the Southern Ocean pelagic ecosystem (Quillfeldt et al. 2005) and of cephalopods worldwide (Takai et al. 2000) also showed a similar decline in $\delta^{13} \mathrm{C}$ values with increasing latitudes in the Southern Hemisphere. However, the 2 reviews included some very negative values that are likely to be due, in part, to a lipid effect as well as differences in isotopic discrimination among different tissue types. Lipids are depleted in ${ }^{13} \mathrm{C}$ compared to proteins (Tieszen et al. 1983). Consequently, lipids must be removed from fatty tissues for a better understanding of their carbon signature, including the determination of animal feeding areas.

Results from various oceanographic cruises suggest that $\delta^{13} \mathrm{C}$ values of surface POM in oceanic waters are not linearly related to latitudes. Instead, latitudinal changes are stepwise, with little variation in POM carbon signature within a given water mass and abrupt changes at fronts. For example, relatively constant values were observed across the Antarctic Zone with fairly steep increases across the Polar and Subantarctic Fronts (Trull \& Armand 2001) and the Subtropical Front (François et al. 1993). The spatial accuracy of the determination of foraging areas of consumers using their $\delta^{13} \mathrm{C}$ values thus operates at a large geographical scale, that of water masses and fronts (10s to 100 s of 
$\mathrm{km}$ in latitude). Consequently, birds that are known to forage in the same water masses should have the same tissue $\delta^{13} \mathrm{C}$ values. Indeed, no difference in $\delta^{13} \mathrm{C}$ signatures was found in southern rockhopper and macaroni penguins from Crozet Islands. When breeding in sympatry, the 2 species overlapped greatly in their feeding habits, including foraging zones (Hull 1999). The importance of water masses and fronts in shaping the $\delta^{13} \mathrm{C}$ values of oceanic consumers is also underlined by the identical $\delta^{13} \mathrm{C}$ values of king penguins breeding at Crozet and Kerguelen Islands. An identical signature is consistent with satellite tracking showing that the 2 populations forage in the same marine environment, the Polar Front (Charrassin \& Bost 2001, Bost et al. 2002). Birds from Crozet and Kerguelen, however, travel to very distinct geographical areas, thus pointing out that the method gives valuable latitudinal estimates of the foraging zones but, in contrast, $\delta^{13} \mathrm{C}$ values gives no indication about longitude.

Unlike $\delta^{13} \mathrm{C}$ values, $\delta^{15} \mathrm{~N}$ values of oceanic surface POM show no obvious trends with latitudes in the Southern Ocean, except a sharp increase at its northern boundary, the Subtropical Front (Altabet \& François 1994, Lourey et al. 2003). Accordingly, there was no relationship between the nitrogen isotopic signature of penguin blood and latitude (Fig. 1). Since the enrichment per trophic level is striking in $\delta^{15} \mathrm{~N}$ (i.e. of the order of $3.3 \%$, McCutchan et al. 2003), the $\delta^{15} \mathrm{~N}$ values of penguins should be strongly affected by differences in their feeding habits and in those of their prey. Indeed, the $\delta^{15} \mathrm{~N}$ values of fish eating species (emperor and king penguins) were well above those of crustacean eaters (southern rockhopper and macaroni penguins). Dietary differences cannot, however, explain the $2.4 \%$ o higher signature of northern than southern rockhopper penguins that forage well north and south of the Subtropical Front, respectively. The higher $\delta^{15} \mathrm{~N}$ value characterizing the base of the foodweb in warm waters is therefore the most likely explanation for that difference. It is in agreement with the elevated $\delta^{15} \mathrm{~N}$ values consistently associated with high $\delta^{13} \mathrm{C}$ values indicating feeding in subtropical waters in oceanic seabirds (Cherel et al. 2000, 2006, Quillfeldt et al. 2005).

\section{Variation of penguin $\delta^{13} \mathrm{C}$ values at Kerguelen Islands}

At the spatial scale of a subantarctic archipelago, the $\delta^{13} \mathrm{C}$ values of penguins indicated the distance of their foraging areas from the coast (Fig. 2). In addition to latitudinal variations, the marine environment is characterized by benthic or inshore foodwebs that are more enriched in ${ }^{13} \mathrm{C}$ than pelagic or offshore foodwebs (France 1995). As previously described in seabird com- munities from the North Pacific (Hobson et al. 1994), this isotopic effect appears to integrate both a horizontal (inshore/offshore) and a vertical (benthic/pelagic) component, depending on the ultimate sources of carbon driving the foodweb. Little is known about the trophic structure of subantarctic ecosystems using stable isotopes. At the Prince Edward Islands, the 2 main types of primary producers have distinctly different $\delta^{13} \mathrm{C}$ values, with kelp having a much more positive signature than POM, and nearshore POM being slightly enriched in ${ }^{13} \mathrm{C}$ when compared to offshore POM (Kaehler et al. 2000). The benthic/pelagic gradient thus appears much more pronounced than the inshore/offshore gradient (about 10 and $1 \%$, respectively). In Kerguelen penguins, the difference in $\delta^{13} \mathrm{C}$ values amounted to $4.1 \%$ between open-sea gentoo penguins and the oceanic king penguins, suggesting a role of both the benthic/pelagic and the inshore/ offshore gradients in shaping the penguin community. Indeed, the offshore king and crested penguins forage in the pelagic zone (Charrassin \& Bost 2001, Tremblay \& Cherel 2003), but open-sea gentoo penguins dive both pelagically and benthically and accordingly feed on both pelagic and benthic prey (Lescroël et al. 2004, Lescroël \& Bost 2005).

At Kerguelen, the highest penguin $\delta^{13} \mathrm{C}$ value was found in closed-sea gentoo penguins living in Morbihan Bay. This high $\delta^{13} \mathrm{C}$ value was likely a result not only of a benthic influence, but also from high phytoplankton $\delta^{13} \mathrm{C}$ values at the base of the pelagic foodweb because summer primary productivity is extremely elevated there (Razouls et al. 1997) and the $\delta^{13} \mathrm{C}$ value of phytoplankton is positively linked to productivity (Laws et al. 1995). Whatever the explaining mechanisms are, however, a main point is that blood $\delta^{13} \mathrm{C}$ values allowed us to differentiate sub-populations of the same penguin species foraging in different environments at a small spatial scale, here within the same archipelago.

\section{Practical considerations and conclusion}

In agreement with latitudinal and inshore/offshore and benthic/pelagic $\delta^{13} \mathrm{C}$ gradients at the base of the foodweb, our study shows that the $\delta^{13} \mathrm{C}$ signature of seabirds is an efficient tool for investigating their foraging habitats at various spatial scales. Combined with $\delta^{15} \mathrm{~N}$ analyses to help elucidate trophic effects, the method is likely applicable to other groups of consumers (Cherel \& Hobson 2005) to depict the patterns of animal movements and migration. The method, however, had 2 limitations, that need careful examination in order to interpret the data correctly. First, as pointed out above, the $\delta^{13} \mathrm{C}$ values of oceanic POM 
clearly show a latitudinal gradient, but there is no indication of a longitudinal one, thus explaining why some birds foraging in different areas but in identical water masses have identical $\delta^{13} \mathrm{C}$ values. Second, latitudinal and inshore/offshore and benthic/pelagic gradients induce an overlap in the most positive $\delta^{13} \mathrm{C}$ values of consumers, which can lead to strong misinterpretations of foraging origins. This is well illustrated in our study by comparing the blood $\delta^{13} \mathrm{C}$ values of the subtropical northern rockhopper penguin with those of open-sea and closed-sea gentoo penguins from Kerguelen Islands. The very positive $\delta^{13} \mathrm{C}$ values of gentoo penguins can be erroneously interpreted as birds foraging in oceanic subtropical waters (open-sea penguins) and even further north (closed-sea penguins). Consequently, a good knowledge of the biology of the studied animals, including the use of other methods, both conventional (food analysis, provisioning strategies) or not (electronic devices) are often essential to the interpretation of isotopic results and vice versa.

In the present study, the isotopic signatures of surface POM and penguin prey were not investigated. Future studies should include complementary measures to assess spatio-temporal variations of $\mathrm{POM} \delta^{13} \mathrm{C}$ values, their progressive integration through the foodweb, and thus their influence on the $\delta^{13} \mathrm{C}$ values of consumers. This is essential if the stable isotopes are to be routinely used to study foraging ecology of marine predators.

Finally, a consideration inherent to the stable isotope method refers to the consistent differences in isotopic discrimination that have been found among consumer tissues (Hobson \& Clark 1992, Vanderklift \& Ponsard 2003). Feathers, for example, are generally more enriched in ${ }^{15} \mathrm{~N}$ and ${ }^{13} \mathrm{C}$ than avian blood (Kelly 2000, Cherel et al. 2005b). Nevertheless, certain biochemical and physiological properties (protein turnover rate, metabolic routing) characterizing various tissues are similar across taxa. Consequently, comparison of isotopic signatures between individuals and taxa must be made on the same tissues to minimize inter-tissue differences.

Acknowledgements. We thank the numerous fieldworkers who collected blood samples in Adélie Land, and in Kerguelen, Crozet and Amsterdam Islands, P. Healy for preparing samples for stable isotope analysis and M. Stocki for running stable isotope samples at the Department of Soil Science, University of Saskatchewan. The work is a part of the Programme No. 109 of the Institut Polaire Français Paul Emile Victor (IPEV).

\section{LITERATURE CITED}

Altabet MA, François R (1994) Sedimentary nitrogen isotopic ratio as a recorder for surface ocean nitrate utilization. Global Biogeochem Cycles 8:103-116
Barlow KE, Croxall JP (2002) Seasonal and interannual variation in foraging range and habitat of macaroni penguins Eudyptes chrysolophus at South Georgia. Mar Ecol Prog Ser 232:291-304

Best PB, Schell DM (1996) Stable isotopes in southern right whale (Eubalaena glacialis) baleen as indicators of seasonal movements, feeding and growth. Mar Biol 124: 483-494

Bost CA, Zorn T, Le Maho Y, Duhamel G (2002) Feeding of diving predators and diel vertical migration of prey: king penguins' diet versus trawl sampling at Kerguelen Islands. Mar Ecol Prog Ser 227:51-61

Charrassin JB, Bost CA (2001) Utilisation of the oceanic habitat by king penguins over the annual cycle. Mar Ecol Prog Ser 221:285-297

Cherel Y, Hobson KA (2005) Stable isotopes, beaks and predators: a new tool to study the trophic ecology of cephalopods, including giant and colossal squids. Proc R Soc Lond B 272:1601-1607

Cherel Y, Ridoux V (1992) Prey species and nutritive value of food fed during summer to king penguin Aptenodytes patagonica chicks at Possession Island, Crozet Archipelago. Ibis 134:118-127

Cherel Y, Hobson KA, Weimerskirch H (2000) Using stableisotope analysis of feathers to distinguish moulting and breeding origins of seabirds. Oecologia 122:155-162

Cherel Y, Hobson KA, Bailleul F, Groscolas R (2005a) Nutrition, physiology, and stable isotopes: new information from fasting and molting penguins. Ecology 86:2881-2888

Cherel Y, Hobson KA, Hassani S (2005b) Isotopic discrimination between food and blood and feathers of captive penguins: implications for dietary studies in the wild. Physiol Biochem Zool 78:106-115

Cherel Y, Hobson KA, Weimerskirch H (2005c) Using stable isotopes to study resource acquisition and allocation in procellariiform seabirds. Oecologia 145:533-540

Cherel Y, Phillips RA, Hobson KA, McGill R (2006) Stable isotope evidence of diverse species-specific and individual wintering strategies in seabirds. Biol Lett 2:301-303

France RL (1995) Carbon-13 enrichment in benthic compared to planktonic algae: foodweb implications. Mar Ecol Prog Ser 124:307-312

François R, Altabet MA, Goericke R (1993) Changes in the $\delta^{13} \mathrm{C}$ of surface water particulate matter across the Subtropical Convergence in the SW Indian Ocean. Global Biogeochem Cycles 7:627-644

Hobson KA (1999) Tracing origins and migration of wildlife using stable isotopes: a review. Oecologia 120:314-326

Hobson KA, Clark RW (1992) Assessing avian diets using stable isotopes II: factors influencing diet-tissue fractionation. Condor 94:189-197

Hobson KA, Piatt JF, Pitocchelli J (1994) Using stable isotopes to determine seabird trophic relationships. J Anim Ecol 63: $786-798$

Hobson KA, Gibbs HL, Gloutney ML (1997) Preservation of blood and tissue samples for stable-carbon and stablenitrogen isotope analysis. Can J Zool 75:1720-1723

Hodum PJ, Hobson KA (2000) Trophic relationships among Antarctic fulmarine petrels: insights into dietary overlap and chick provisioning strategies inferred from stableisotope $\left(\delta^{15} \mathrm{~N}\right.$ and $\left.\delta^{13} \mathrm{C}\right)$ analyses. Mar Ecol Prog Ser 198: $273-281$

Hull (1999) The foraging zones of breeding royal (Eudyptes schlegeli) and rockhopper (E. chrysocome) penguins: an assessment of techniques and species comparison. Wildl Res 26:789-803

Kaehler S, Pakhomov EA, McQuaid CD (2000) Trophic struc- 
ture of the marine food web at the Prince Edward Islands (Southern Ocean) determined by $\delta^{13} \mathrm{C}$ and $\delta^{15} \mathrm{~N}$ analysis. Mar Ecol Prog Ser 208:13-20

Kelly JF (2000) Stable isotopes of carbon and nitrogen in the study of avian and mammalian trophic ecology. Can J Zool 78:1-27

Laws EA, Popp BN, Bidigare RR, Kennicutt MC, Macko SA (1995) Dependence of phytoplankton carbon isotopic composition on growth rate and $[\mathrm{CO} 2]_{\mathrm{aq}}$ - theoretical considerations and experimental results. Geochim Cosmochim Acta 59:1131-1138

Lescroël A, Bost CA (2005) Foraging under contrasting oceanographic conditions: the gentoo penguin at Kerguelen Archipelago. Mar Ecol Prog Ser 302:245-261

Lescroël A, Ridoux V, Bost CA (2004) Spatial and temporal variation in the diet of the gentoo penguin (Pygoscelis papua) at Kerguelen Islands. Polar Biol 27:206-216

Lourey MJ, Trull TW, Sigman DM (2003) Sensitivity of $\delta^{15} \mathrm{~N}$ of nitrate, surface suspended and deep sinking particulate nitrogen to seasonal nitrate depletion in the Southern Ocean. Global Biogeochem Cycles 17:1081doi:10.1029/ 2002GB001973

McCutchan JH, Lewis WM, Kendall C, McGrath CC (2003) Variation in trophic shift for stable isotope ratios of carbon, nitrogen, and sulfur. Oikos 102:378-390

Offredo C, Ridoux V (1986) The diet of emperor penguins Aptenodytes forsteri in Adélie Land, Antarctica. Ibis 128: 409-413

Park YH, Gamberoni L, Charriaud E (1993) Frontal structure, water masses, and circulation in the Crozet Basin. J Geophys Res 98:12361-12385

Pütz K (2002) Spatial and temporal variability in the foraging areas of breeding king penguins. Condor 104:528-538

Quillfeldt P, McGill RAR, Furness RW (2005) Diet and foraging areas of Southern Ocean seabirds and their prey inferred from stable isotopes: review and case study of

Editorial responsibility: Howard Browman (Associate Editorin-Chief), Storebø, Norway
Wilson's storm-petrel. Mar Ecol Prog Ser 295:295-304

Razouls S, de Bovée F, Delille D, Fiala M, Mayzaud P (1997) Temporal variability of bacteria, phytoplankton and zooplankton assemblages of the sub-Antarctic Morbihan Bay (Kerguelen Archipelago). In: Battaglia B, Valencia J, Walton DWH (eds) Antarctic communities. Species, structure and survival. Cambridge University Press, Cambridge, p 86-92

Rodary D, Bonneau W, Le Maho Y, Bost CA (2000) Benthic diving in male emperor penguins Aptenodytes forsteri foraging in winter. Mar Ecol Prog Ser 207:171-181

Rubenstein DR, Hobson KA (2004) From birds to butterflies: animal movement patterns and stable isotopes. Trends Ecol Evol 19:256-263

Takai N, Onaka S, Ikeda Y, Yatsu A, Kidokoro H, Sakamoto W (2000) Geographical variations in carbon and nitrogen stable isotope ratios in squid. J Mar Biol Assoc UK 80: 675-684

Tieszen LL, Boutton TW, Tesdahl KG, Slade NA (1983) Fractionation and turnover of stable carbon isotopes in animal tissues: implications for $\delta^{13} \mathrm{C}$ analysis of diet. Oecologia 57: 32-37

Tremblay Y, Cherel Y (2003) Geographic variation in the foraging behaviour, diet and chick growth of rockhopper penguins. Mar Ecol Prog Ser 251:279-297

Trull TW, Armand L (2001) Insights into Southern Ocean carbon export from the $\delta^{13} \mathrm{C}$ of particles and dissolved inorganic carbon during the SOIREE iron release experiment. Deep-Sea Res II 48:2655-2680

Vanderklift A, Ponsard S (2003) Sources of variation in consumer-diet $\delta^{15} \mathrm{~N}$ enrichments: a meta-analysis. Oecologia 136:169-182

Wienecke BC, Lawless R, Rodary D, Bost CA and 5 others (2000) Adélie penguin foraging behaviour and krill abundance along the Wilkes and Adélie Land coasts, Antarctica. Deep-Sea Res II 47:2573-2587

Submitted: April 5, 2006; Accepted: May 31, 2006 Proofs received from author(s): December 19, 2006 